\title{
WIARA W TEOLOGII JOSEPHA RATZINGERA/BENEDYKTA XVI
}

U źródeł wiary jest samoobjawienie się Boga człowiekowi: „Niewidzialny Bóg w swojej wielkiej miłości przemawia do ludzi jak do przyjaciół i przestaje z nimi, by zaprosić i przyjąć ich do wspólnoty z sobą". Odpowiedzią natomiast na to zaproszenie jest wiara. Słowo Boże rodzi wiarę w sercu człowieka - twierdzą na podstawie Objawienia dokumenty Kościoła. To dzięki niej powstaje i wzrasta wspólnota wierzących. Samo głoszenie słowa wymaga natomiast odpowiedzi wiary jako zgody i zaangażowania osoby w odniesieniu do przymierza z Bogiem, do którego został zaproszony². W Liście do Rzymian znajdujemy źródło tych sformułowań soborowych i posoborowych: „Jakże więc mieli wzywać Tego, w którego nie uwierzyli? Jakże mieli uwierzyć w Tego, którego nie styszeli? Jakże mieli ustyszeć, gdy im nikt nie głosit? Jakże mogliby im głosić, jeśliby nie zostali postani? Jak to jest napisane: Jak piękne sa stopy tych, którzy zwiastuja dobra nowinę! Ale nie wszyscy dali postuch Ewangelii. Izajasz bowiem mówi: Panie, któż uwierzyt temu, co od nas postyszat? Przeto wiara rodzi się z tego, co się styszy, tym zaś, co się styszy, jest stowo Chrystusa” (Rz 10,14-17).

${ }^{1}$ II Sobór Watykański, Konstytucja dogmatyczna o Objawieniu Bożym Dei Verbum, [dalej KO] 2; Por. Katechizm Kościoła Katolickiego, [dalej KKK] 142.

2 Por. II Sobór Watykański, Dekret o Posłudze i Życiu Kapłanów Presbyterorum ordinis, 4; KKK 1102. 
Wiarę należy określić przede wszystkim w kategoriach charytologicznych - jest ona łaską, darmo danym darem. Ratzingerowska koncepcja wiary burzy przekonania tych, którzy ją za bardzo humanizują, koncentrując się przesadnie na akcie ludzkim, nadprzyrodzoność wiary pozostawiając na drugim planie. Ratzinger daje pierwszeństwo inicjatywie Boga. Wiara jest przestrzenią nadprzyrodzoną, w której spotykają się mysterium człowieka i Mysterium Boga ${ }^{3}$ - to, co Boskie w człowieku. Wiara jest tym misterium, które człowieka obejmuje i przenika tak, że Bóg przez łaskę nadprzyrodzoną może się dostać do jego wnętrza. Jest ona tym, co udoskonala człowieka, stanowiącego już dla siebie samego pewnego rodzaju tajemnicy ${ }^{4}$.

W doktrynie chrześcijańskiej bowiem przedmiot wiary to nie abstrakcyjna i teoretyczna formuła, nie zajmuje się nim więc jedynie teologia spekulatywna. Przedmiotem wiary jest osoba - Jezus Chrystus. Wiara dla chrześcijanina jest ostatecznie osobistym spotkaniem z Jezusem z Nazaretu. Choć naturalnym światłem rozumu ludzkiego można z rzeczy stworzonych poznać Boga, to jednak Kościół twierdzi stanowczo, że spodobało się Bogu objawić rodzajowi ludzkiemu, inną

3 W odniesieniu do pojęcia Mysterium lepiej jest zachować zapis łaciński, wielką literą, aby przypomnieć jego znaczenie teologiczne, do którego, często odwoływał się Joseph Ratzinger/Benedykt XVI. W potocznej polszczyźnie łacińskie pojęcie mysterium jest tłumaczone - poza nielicznymi wyjątkami - za pomocą terminu „tajemnica”; czasem można spotkać słowo „misterium” (spolszczenie z łaciny). Słowo „tajemnica” zasłania jednak właściwe znaczenie teologiczne. Potocznie oznacza „coś ukrytego, skrytego, jakiś sekret, którego nie wolno ujawnić”, podczas gdy w teologii - wręcz odwrotnie - termin ten określa sensu stricto zamiar Bożego samoobjawienia się w Chrystusie, abyśmy przez Jego Osobę mogli dojść do poznania Boga samego (por. A. Panaro, Wiara i Mysterium. Prymat Bożego daru w teologii Benedykta XVI, Lublin 2014, s. 25).

4 „Tajemnica człowieka wyjaśnia się naprawdę dopiero w tajemnicy Słowa Wcielonego. Albowiem Adam, pierwszy człowiek, był figurą pierwszego, mianowicie Chrystusa. Chrystus nowy Adam, już w samym objawieniu tajemnicy Ojca i Jego Miłości objawia w pełni człowieka samemu człowiekowi i okazuje mu najwyższe jego powołanie". II Sobór Watykański, Konstytucja duszpasterska o Kościele w świecie współczesnym Gaudium et spes, 22. Por. Jan Paweł II, Encyklika Redemptor hominis, 8, 10, 14. 
i nadprzyrodzoną drogą, siebie samego oraz odwieczne postanowienia swej woli ${ }^{5}$. Wiara dla Ratzingera to właśnie przede wszystkim Mysterium, dotknięcie samej natury Boga. Używa on tego terminu głównie w znaczeniu biblijnym. W Nowym Testamencie termin $\mu v \sigma \tau \eta ́ \rho ı o v^{6}$ odnośni się w sposób szczególny do istoty Samego Boga (por. Kol 1,26-27; 2,2). Powrót do biblijnego znaczenia „Mysterium”które cechowało teologię patrystyczną ${ }^{7}$ - wiąże się u Ratzingera m.in. z gruntowną znajomością teologii św. Augustyna. Katolicka teologia posoborowa próbuje znaleźć w swoim podstawowym wykładzie wiary złoty środek między czynnikiem Boskim i ludzkim. Ratzinger jest przedstawicielem tej właśnie koncepcji, potwierdzonej już na Soborze Watykańskim I. W obecnej epoce, po Soborze Watykańskim II $^{8}$, koncepcja ta rozwinęła się i znalazła swe miejsce w najnowszych dokumentach oficjalnego nauczania Kościoła ${ }^{9}$. Niemałą rolę odegrał tu niemiecki teolog Joseph Ratzinger.

5 Por. I Sobór Watykański, [w]: Breviarum fidei, [BF] 641 lub Denzinger H., Schonmetzer A., Enchirydion symbolorum, definitionum et declarationum de rebus fidei et morum, Bologna 1996, [DS] 3004; por. tamże 3026; KO 6.

${ }^{6}$ Por. A. Nichols, The thought of Benedict XVI, s. 114-115. Zob. M. Blaza, D. Kowalczyk, Traktat o sakramentach, [w]: E. Adamiak, A. Czaja, J. Majewski (red.), Dogmatyka, tom 5, Warszawa 2007, s. 221.

7 Por. J. Ratzinger, Moje życie, Częstochowa 2005, s. 71-72. Zob. H. De Lubac, Dramat humanizmu, Kraków 2004, s. 103.

${ }^{8}$ II Sobór Watykański nie był soborem o wierze, jak to miało miejsce w przypadku Soborów od początku historii Kościoła aż do I Soboru Watykańskiego, który miał wielką zasługę w ukształtowaniu głównych treści doktryny wiary katolickiej (Konstytucja dogmatyczna Dei Filius z 1870 r.). Zob. także II Sobór Watykański, Konstytucja dogmatyczna o Kościele Lumen gentium [KK] 9-17;KDK 1-3; 40; KO 4-5.

9 Zob. KKK 37-38; 50-73; Konstytucja Apostolska Fidei Depositum, [w:] KKK, 12-13 (strona) - Przedstawiając strukturę nowego katechizmu, Jan Paweł II używa następujących sformułowań: „Mysterium chrześcijańskie jest przedmiotem wiary (część pierwsza); [...] Czytając Katechizm Kościoła Katolickiego, można dostrzec przedziwną jedność Bożego mysterium i Bożego zamysłu zbawienia, a także centralne miejsce Jezusa Chrystusa". Zob także: FR, 13-15; Kongregacja Nauki Wiary, Deklaracja o jedyności i powszechności zbawczej Jezusa Chrystusa i Kościoła Dominus Iesus, [DI] 7. Zob. też DI 8; 9; 12; 13; 16 


\section{KU DEFINICJI WIARY}

Zgodnie z Pawłowym przesłaniem na temat wiary jako rzeczywistości nadprzyrodzonej, którą otrzymuje się w darze dzięki słuchaniu słowa Chrystusa (Rz 10,17), Ratzinger poszukuje definicji wiary, która by mogła syntetycznie pomóc w uchwyceniu proprium chrześcijaństwa - tego, co właściwe jest w chrześcijaństwie. Znajduje podpowiedź w Księdze proroka Izajasza $(7,9)$ i w analizie żródłosłowia - 'mn (amen). Wychodzi z biblijnego określenia wiary: "Jeśli nie wierzycie, to się nie ostoicie” (Iz 7,9), którą sam dosłownie przetłumaczył: "Jeśli nie będziecie stać przy Jahwe, nie ostoicie się"10. Zwraca uwagę na grę słów, nieprzetłumaczalną na języki współczesne, która dotyczy źródłosłowu - 'mn (amen), i próbuje zagłębiać się $\mathrm{w}$ interpretację jego różnorodnych znaczeń. Zaciekawić może urozmaicenie możliwości tłumaczeń, które jednak w ogólnej analizie etymologicznej składają się w jedną całość, ukierunkującą ku właściwej definicji wiary w duchu Objawienia, a mianowicie: prawda, stałość, bezpieczny grunt, podstawa; ale również: wierność, zaufać, powierzyć się, stanąć przy czymś, wierzyć w coś. Głównym wnioskiem tej analizy jest według Ratzingera to, że wiara w Boga jest „trwaniem przy Bogu, poprzez co osiąga człowiek trwałe oparcie w życiu"11. Gdybyśmy zatem brali pod uwagę przekład Septuaginty, zauważylibyśmy radykalne zmiany w tłumaczeniu tych samych zwrotów, na które miał wpływ filozoficzny kontekst kulturalny języka greckiego, skutkiem czego definicja wiary uległa całkowicie innej interpretacji: "Jeśli nie wierzycie, to i nie rozumiecie"12. Taka intelektualizacja wiary biblijnej zamieniła owo „stanie na mocnym gruncie słowa Bożego, któremu można zaufać”, czyli rzeczywistość nadprzyrodzoną związaną z byciem przy samym Bogu. Łączyła ją natomiast $z$ rozumem i rozumieniem, które ograniczały wiarę do zakresu czysto ludzkiego i oddalały ją coraz bardziej od Mysterium

\footnotetext{
10 J. Ratzinger, Wprowadzenie w chrześcijaństwo, Kraków 2007. s. 67.

11 Tamże.

12 Tamże.
} 
Boga. Ponadto zajmowała się wyłącznie jednym tylko aspektem rzeczywistości człowieka (rozumem), lekceważąc resztę (wolę, duszę, ciało) i przez to popadała w błąd jego przesadnej gloryfikacji. $\mathrm{Na}$ skutek takiego podejścia do wiary, należącego do kategorii myślenia rachującego, przenosi się ją na płaszczyznę takiego typu wiedzy, zwanej przez Ratzingera wiedzą o wykonalnym, a która do wiary nie należy. Wiara jest postawą duchową równorzędną wiedzy ${ }^{13}$; nie jest $\mathrm{z}$ nią jednak tożsama ani współmierna, ponieważ wiara jest odpowiedzią na pytania o istotę rzeczy i egzystencji. Dlatego jest nadaniem sensu, bez którego człowiek nie znalazłby dla siebie miejsca w świecie, sens zaś oznacza podstawy, na których człowiek może opierać swoją egzystencję. Wiara, powiada Ratzinger, należy do myślenia rozważającego, czyli do podejścia do rzeczywistości, które zastanawia się nad sensem istnienia tego, co nas otacza i nas samych. Sensu nie można wymyśleć, „sens, jaki człowiek sam wymyśli, nie jest ostatecznie żadnym sensem"'14. Tu rozumiemy, że Kartezjańskie hasło - cogito ergo sum - które zachęcało do wyłącznie dedukcyjnego podejścia do wiary - zawadziło o rzeczywistość, którą jedynie można przyjąć: o egzystencję.

Z jednej strony owo „stanie”, które według hebrajskiego tekstu jest treścią wiary, ma coś wspólnego z „rozumieniem”; z drugiej strony właściwa interpretacja tekstu biblijnego wskazuje na „rozumienie”, które utożsamia się z samym logosem i z prawdą ${ }^{15}$. Odwołuje się do poszukiwania prawdy $\mathrm{i}$ istoty rzeczy, a nie do wiedzy w sensie pozytywistycznym, rezygnuje odgórnie z pytania o prawdę, nie pyta o istotę rzeczy: „o to, czym są rzeczy same w sobie, ale tylko o to, jaką funkcję mogą spełnić dla nas"16. Rozumienie, które ogranicza się do wiedzy, wynikającej z czysto ludzkiej kalkulacji i wyciągania wniosków z proponowanych hipotez, potwierdza jedynie, że jakaś

13 Chodzi o wiedzę rozumianą w sensie pozytywistycznym jako to, co można obliczyć, zbadać, zmierzyć.

14 J. Ratzinger, Wprowadzenie, dz. cyt., s. 71.

15 Por. tamże, s. 73-77.

16 Tamże, s. 74. 
rzeczywistość jest doświadczalna i użyteczna dla nas, dzięki poprawności obliczeń; jednakże takie rozumienie rzeczywistości dystansuje się zupełnie od pytania o prawdę i nie jest nią zainteresowane.

Biblijny tekst przywołuje znaczenie hebrajskiego słowa amen, które zawiera zakres znaczeniowy terminu logos. Oba terminy, choć nie są do końca przetłumaczalne, wskazują na „sens, oparcie i prawdę". Ratzinger, poszukując biblijnej definicji wiary i zaznaczając, że termin ,wierzyć” i ,amen” w języku hebrajskim mają ten sam źródłosłów, o którym wcześniej mówiliśmy, dochodzi do wniosku, że ,(słowo) «amen» powtarza [...] na swój sposób to, co znaczy wyraz «wierzyć»»"17, czyli „stanąć z pełnym zaufaniem na określonym gruncie nie dlatego, że ja tę postawę stworzyłem i sprawdziłem, ale właśnie dlatego, że jej nie stworzyłem i nie mogę jej sprawdzić; powierzyć się temu, czego nie możemy sami wykonać, powierzyć się temu jako sensowi świata, który dopiero otwiera przed nami wolność działania"18.

Wyraz ,amen” zawiera w sobie takie pojęcia, jak: zaufanie, zawierzenie, wierność, stałość, bezpieczny grunt, trwanie, prawda. Autor interpretuje tę wskazówkę etymologiczną jako potwierdzenie, że wiarę w najgłębszym biblijnym znaczeniu określa się terminem „amen”, który oznacza to, na „czym człowiek może się ostatecznie oprzeć"' ${ }^{19}$, co stanowi sens jego życia, a jest nim tylko prawda - logos.

Jak można zauważyć, Ratzinger za pomocą egzegezy tekstu starotestamentalnego wnioskuje, że wiara i jej treść należą do płaszczyzny nadprzyrodzonej Boga Samego, Logosu20 - prawdy, Mysterium, które leży u podstaw egzystencji całego kosmosu i człowieka, nadając wszystkiemu sens.

17 Tamże, s.73.

18 Tamże.

19 Por. Tamże, s. 74.

20 J. Ratzinger/Benedykt XVI rozumie termin logos chrystologicznie (por. $\mathrm{J}$ 1, 1-18), dlatego również w tym przypadku trzeba preferować zapis Logos z dużej litery. 


\section{TEOLOGIA WIARY}

Zastanówmy się teraz nad samym zagadnieniem wiary. Nie jest ona dla Ratzingera jakimś drugorzędnym, gorszym, nieprecyzyjnym gatunkiem wiedzy ${ }^{21}$; nie jest nawet jej surogatem ${ }^{22}$. Jest rozumieniem i sensem egzystencji - jak wyżej mówiliśmy - zarówno w sensie najbardziej potocznym, dotyczącym codzienności człowieka, jak i w wymiarze najbardziej naukowym: metafizycznym, kosmologicznym i personalistycznym ${ }^{23}$. Wiara posiada aksjologiczną strukturę ${ }^{24}$. Patrząc pozytywnie, jest ona niezbędna w życiu człowieka. Bez wiary człowiek nie mogłoby funkcjonować, każdy musiałby „,zaczynać od początku", nie ufając innym ludziom - życie ludzkie stałoby się wręcz niemożliwe. Jest ona nie tylko podstawą bycia dla chrześcijan, ale stanowi podstawę codziennego życia każdego człowieka ${ }^{25}$. Mimo to jest ona współcześnie odrzucana jako wyraz rzekomej niewiedzy ${ }^{26}$.

Ratzinger nigdy nie oddziela sacrum od profanum, filozofii od teologii, teorii od praktyki, dlatego nie oddziela również rozumienia i sensu egzystencji od wiary, rozumienia od wiary, a także wiary od Mysterium. Tym, co Ratzinger nazywa „rozumieniem”, zajmuje się według niego nie tylko filozofia, ale i teologia, która może wyrastać tylko z wiary ${ }^{27}$. Teologia jest - zdaniem Ratzingera - rozumieniem w pełnym tego słowa znaczeniu. Kiedyś zdefiniował ją jako „rozu-

${ }^{21}$ Zob. A. Panaro, dz. cyt., s. 39-46.

22 Por. J. Ratzinger, Patrzeć na Chrystusa, Kraków 2005, s. 11.

${ }^{23}$ Zob. tamże, s. 9-10.

${ }^{24}$ Zob. tamże, 11. Zagadnieniem wiary w myśli teologicznej i w dziełach J. Ratzingera zajmują się poszczególni autorzy, do których odsyłamy: zob. A. Nichols, dz. cyt., s. 105-110; J. Ratzinger-Benedetto XVI, Fede, ragione, verità e amore, Torino 2009, s. 9-52.

25 Zob. J. Ratzinger, Patrzeć na Chrystusa, dz. cyt., s. 9; B. Seboüe, Wierzę, Warszawa-Poznań 2000, s. 30-43. Drugi z kolej autor, podobnie jak Ratzinger, twierdzi, że u podstaw funkcjonowania naszego społeczeństwa stoi akt wiary. Akt wiary stanowi codzienność naszego życia: ,jest zasadniczym aktem ludzkiej kondycji, aktem szlachetnym i prawdziwie ludzkim”. B. Seboüe, dz. cyt., s. 33.

${ }^{26}$ Por. J. Ratzinger, Patrzeć na Chrystusa, dz. cyt., s. 10.

27 Por. J. Ratzinger, Wprowadzenie, dz. cyt., s. 76. 
miejące, trzymające się logosu (racjonalne, rozumnie pojmujące) mówienie o Bogu"28. Tak pojęta teologia wynika z wiary, bez niej przestaje mieć rację bytu. Wiara jest jej „,podstawowym zadaniem”29.

\section{WIARA I RZECZYWISTOŚĆ}

Wiara jest tym „innym sposobem dojścia do rzeczywistości”30, ponieważ jej istoty nie można objąć w całości ani naszym doświadczeniem zmysłowym, ani umysłowym. Jest ona innym sposobem dojścia do rzeczywistości, ponieważ „wzrokiem, słuchem i dotykiem” tego nie może uczynić. Oznacza ona inną, ,zasadniczą postawę wobec bytu, wobec egzystencji, siebie samego i całej rzeczywistości; oznacza opowiedzenie się za tym, że to, czego nie można ujrzeć, co nie może w żaden sposób stanąć w polu widzenia człowieka, nie jest czymś rzeczywistym, lecz odwrotnie, że to, czego nie można ujrzeć, jest właściwą rzeczywistością, która utrzymuje i umożliwia wszystko"si.

Dla egzystencji człowieka niezbędne okazuje się to, co przerasta możliwości poznania zmysłowego. Wejście na płaszczyznę wiary oznacza więc w istocie rzeczy wyrwanie się spod prawa naturalnego ciążenia i pokonanie go. Człowiek w akcie wiary odwraca się wewnętrznie od tego, co go naturalnie pociąga jedynie ku temu, co widzialne i dotykalne. „Człowiek musi się wewnętrznie odwrócić, aby dojrzeć, jak wiele traci z tego, co istotne, gdy idzie za swym ciążeniem naturalnym. Musi się odwrócić, aby poznać, jak jest ślepy, gdy wierzy tylko temu, co widzą jego oczy"32 - pisze Ratzinger. Pierwszym warunkiem wiary - twierdzi dalej - jest zwrot egzystencji pokonujący w człowieku naturalne ciążenie. Ten zwrot w bytowaniu człowieka nazywa „odwróceniem i na-wróceniem”. W nim człowiek

\footnotetext{
28 Tamże.

29 Zob. tamże.

30 Tamże, s. 47.

31 Tamże.

32 Por. tamże, s. 48.
} 
odkrywa, że się łudzi, gdy idzie jedynie za tym, co uchwytne. Wiara jest swoistego rodzaju skokiem ,poprzez bezdenną przepaść z napierającego na człowieka dotykalnego świata" ${ }^{33}$.

Dla Ratzingera wiara w to, co niewidzialne i niedotykalne jest rozstrzygnięciem angażującym głębię ludzkiej egzystencji i domagającym się od człowieka zwrotu, w następstwie wyboru i decyzji woli. Przygoda wiary jest ryzykiem, ponieważ przyjmuje się na jej obszarze ,jako rzeczywiste i podstawowe to, czego bezpośrednio nie widać" 34 .

Postawą dyskursu Ratzingerowskiego jest pokazanie najpierw granic nowożytnego pojmowania rzeczywistości, aby dopiero później znaleźć miejsce dla wiary.

Dla Ratzingera podejmować tematykę wiary oznacza „rościć sobie prawo dostępu do rzeczywistości”, czyli wnikać i mówić o Mysterium. Wiara jest dla niego dotknięciem natury Boga i Jego transcendencji w stosunku do świata. Bóg jednak znajduje się poza polem widzenia człowieka - Boga nikt nigdy nie widział; ten Jednorodzony Bóg, który jest w tonie Ojca [o Nim] pouczyt $(\mathrm{J} 1,18)^{35}$. Można stwierdzić zgodnie z tym, co powiedziano wyżej, że wiara jest sensem i oparciem ludzkiej egzystencji, zaś w sensie pojęcia Mysterium oznacza rozumienie. Należą one do siebie, ale łączy je również Mysterium Logosu, którym jest Sam Bóg ${ }^{36}$. Wiara rozumiana w kontekście „właściwego pojęcia Mysterium” - podkreśla autor - „nie oznacza negacji rozumu, ale raczej chce umożliwić wiarę jako rozumienie" ${ }^{37}$. Za pomocą wiary człowiek jest w posiadaniu klucza do wnętrza istoty rzeczywistości,

33 Por. tamże.

${ }^{34}$ Por. Tamże, s. 48-49.

35 Zob. A. Nichols, Myśl Benedykta XVI-Wprowadzenie do myśli teologicznej Josepha Ratzingera, Kraków 2006, s. 147.

${ }_{36}$ Por. J. Ratzinger, Wprowadzenie, dz. cyt., s. 75-77. „Wiara i rozumienie należą do siebie nie mniej niż wiara i stanie przy czymś, bo stanie przy czymś i rozumienie są nierozłączne. Greckie tłumaczenie zdania Izajasza o wierze i ostaniu się odsłania perspektywy nieodłączne od treści Biblii, jeśli nie ma być ona zepchnięta w sferę marzycielstwa czy sekciarstwa". Tamże, s. 76-77.

37 Tamże, s. 75. 
rzeczy samej w sobie, do zasady egzystencji wszystkiego na czele z człowiekiem. To ,ja wierzę" może rzeczywiście rozszerzać świat. Jest ono dostępem do zrozumienia świata, jakie posiada Bóg Sam. Wiara jest wejściem w transcendencję: w Mysterium Boga Samego.

\section{WIARA I NAWRÓCENIE}

Joseph Ratzinger mówi o potrzebie zmiany kierunku. Człowiek dzisiejszy jest ukierunkowany na samego siebie. Pożytkiem drogi do wiary jest więc zmiana kierunku i podjęcie drogi do Mysterium. Zmiana kierunku, którą Ratzinger nazywa „odwróceniem” i „nawróceniem się”, polega na wyzwoleniu człowieka z niewoli antropocentryzmu, który jest typowy dla nowożytnego humanizmu ateistycznego. Człowiek, zwłaszcza w epoce oświecenia, chciał się wyzwolić spod dominacji chrześcijańskiego teocentryzmu. Tym samym znalazł się pod jarzmem humanizmu, gdzie nad drugim człowiekiem - często bezlitośnie - dominuje drugi człowiek. W obecnych czasach - twierdzi Ratzinger - trzeba pomóc człowiekowi, by zmienił kierunek swojego istnienia i zanurzył się w Mysterium. Problemem dla współczesnego człowieka staje się niewiadoma związana z $M y$ sterium. Często w tym kontekście mówi się o niemożności dotarcia do istoty rzeczywistości. Popełnia się tym samym metodologiczny błąd, polegający na przesadnym oparciu się na możliwościach rozumu, a także na wierze jedynie w to, co zostało wykonane i na idei samorozwoju, który miałby polegać na realizowaniu tego tylko, co jest w ludzkim mniemaniu wykonalne.

Nawrócenie, o którym mówi Ratzinger, polega na tym, że człowiek zwraca się ku Mysterium z tęsknoty za sensem, oparciem i prawdą. Bóg obdarzył człowieka tęsknotą za prawdą i zrozumieniem. W drodze do prawdy, nie skreślając a priori (jak to robiły filozofie postoświeceniowe) możliwości rozpoznania w granicach umiejętności swojego intelektu tego, co go przerasta, wpatruje się w blask u Mysterium, który rozpromienia się na horyzoncie. Rozum musi wtedy, jak obrazowo ujmuje niemiecki teolog, „żebrać pomocy u wiary”. Wiara bowiem jest sposobem na uchwycenie tego, co przerasta człowieka: 
Mysterium, transcendencji, samej natury Boga. Rozumienie w ujęciu Ratzingerowskim oznacza ,uchwycenie i pojęcie sensu, otrzymanego jako oparcie" 38 .

Wiara polega więc na nawróceniu, czyli na powrocie do Mysterium, transcendencji, do Boga. Ratzinger używa wyrazu „,nawrócenie", odwołując się wyraźnie do jego etymologii w języku greckim, która wskazuje między innymi na zwrot ku Bogu i Jego Mysterium. Wiara jest darem danym darmo. Chrześcijaństwo głosi bowiem ,prymat tego, co otrzymane" nad tym, co osiągnięte własnymi siłami. „Wiara jest nadaniem sensu [...], to znaczy podstawy, na której opiera się cała nasza egzystencja, nie można [go] sobie stworzyć; można go tylko przyjąć"39. Z koncepcji teologicznej Ratzingera wyłania się zasada pierwszeństwa inicjatywy Bożego daru i obdarowywania człowieka. „Chrześcijański humanizm i pozytywizm”, czyli chrześcijańskie dowartościowanie człowieka stworzonego na obraz i podobieństwo Boga $(\mathrm{Rdz} 1,26)$, polegają na tym, że w ramach logiki upodobania Stwórcy do człowieka, po grzechu pierworodnym, Bóg wychodzi naprzeciw człowiekowi ze swoją inicjatywą zbawczą, z miłością i zaproszeniem do wejścia w relację z Nim ${ }^{40}$. Chrześcijański pozytywizm polega ostatecznie na spotkaniu Mysterium Boga i człowieka w osobie Jezusa z Nazaretu. Zgorszenie, które leży w sercu chrześcijaństwa, polega na koncepcji Boga chrześcijan. To Bóg samoobjawiający się człowiekowi, wkraczający z własnej inicjatywy w obszar historii ludzkiej. Bóg chrześcijan jest Bogiem Objawienia, którego pełnię stanowi osoba Jezusa Chrystusa. To Bóg

\footnotetext{
38 Por. Tamże, s. 76.

39 Tamże, s. 70-71.

${ }^{40} \mathrm{O}$ tym, że inicjatywa należy do Boga zob. J. Puyo, Y. Congar, Życie dla prawdy, Jean Puyo rozmawia z ojcem Y. Congarem, Warszawa 1982. „Bóg nie jest rzeczywistością, którą można uchwycić przez jakąś dowolną działalność, posiada inicjatywę we wszystkim. To znaczy, że On nam daje siłę, dzięki której możemy iść ku Niemu. Jest to koncepcja wybitnie ewangeliczna przenikająca pisma św. Pawła" (52).
} 
transcendentny, a jednocześnie immanentny, w którym łączą się skrajności oddalenia i bliskości, koegzystuje maximum i minimum ${ }^{41}$.

Wiara jest więc kroczeniem w kierunku Mysterium Boga samoobjawiającego się w historii. Jego tajemnica polega nie tylko na Jego inności, wszechmocy i transcendencji, ale i na tym, że dał się dotknąć i objąć w człowieku, w ciele ludzkim, w historii. Wiara jest Mysterium nie dlatego, że jest utajoną rzeczywistością, lecz dlatego, że jest kluczem hermeneutycznym do otwarcia historii i ujęcia w niej tajemnicy $^{42}$.

\section{WIARA JAKO DAR I ZADANIE}

Chrześcijański pozytywizm jest powodem zgorszenia dla współczesnego radykalizmu antropocentrycznego, dla dzisiejszego podejścia naukowego, ponieważ bazuje na zasadzie prymatu „tego, co otrzymane". Ratzinger twierdzi, że dowartościowaniem człowieka jako poszukującego sensu, oparcia, rozumienia i prawdy w odniesieniu do bytu jest uznawanie prymatu tego, co otrzymuje się w darze. Wiara o tyle jest Mysterium - a ono z kolei oznacza odsłonięcie i uchwycenie natury Boga - o ile jest darem darmo danym. Jest ona po prostu darem nadprzyrodzonym.

Jeśli nikt, zdaniem Ratzingera, „nie może znaleźć inaczej Boga, jak tylko wychodząc Mu naprzeciw jako Temu, który przychodzi i który oczekuje i wymaga naszego zaangażowania", to $z$ tego wynika, że w tym punkcie przewidziany jest przez Stwórcę kreatywny i aktywny udział człowieka ${ }^{43}$. Bierność nie należy do pojętej w kategorii daru wiary, ponieważ będąc darem nadprzyrodzonym, który w istocie dotyczy Mysterium Boga samego, wymyka się spod kontroli człowieka, który nigdy jej nie posiądzie w całości i definitywnie. Gdyby tak było, to wiara stałaby się jedynie wiedzą, tymczasem jest ona zawierzeniem rzeczywistości, której nie widzimy (por. Hbr 11,1).

\footnotetext{
${ }^{41}$ Por. J. Ratzinger, Wprowadzenie, dz. cyt., s. 244-248.

42 Por. A. Nichols, The thought..., dz. cyt., s. 106-107.

43 Zob. J. Ratzinger, O sensie bycia chrześcijaninem, Kraków 2006, s. 36.
} 
Człowiek powinien przyswajać ją jako dar nieustannie, „oddając mu się jako czemuś, co jest większe ode mnie" i mnie przerasta ${ }^{44}$. Wiara zresztą może słabnąć albo wzrastać i być udoskonalana tak samo, jak może zniknąć: nie jest dana raz na zawsze. Według Ratzingera ma ona coś z przygody i ryzyka, oznacza ,skok w tajemnicę”, w związku z czym potrzebuje stałego zaangażowania człowieka z punktu wiedzenia przede wszystkim jego wolnej woli ${ }^{45}$.

Darmowość daru nadprzyrodzonego nie przeczy kreatywności ludzkiej, ponieważ za pomocą wiary człowiek jest zdolny nadać czemukolwiek sens pod warunkiem, że najpierw ją otrzymuje i przyjmuje. Bóg daje człowiekowi zdolność odczytywania sensu ludzkiego doświadczenia i życia, dlatego za pośrednictwem wiary może on stać przy rzeczywistości jako takiej: rozumieją, kontemplować, obserwować od zewnątrz, a również wnikać w nią. Wniknąć można jedynie w to, co się po prostu widzi i dotyka, ponieważ to, co człowiek otrzymuje w darze, staje się jego udziałem.

Złączenie wiary ze zrozumieniem, sensem i prawdą, z rzeczywistością Logosu staje się klarowne, gdy zakłada się, że, jak już mówiliśmy, Ratzinger rozumie te terminy personalistycznie, chrystologicznie, eklezjologicznie i sakramentologiczne, ${ }^{46}$.

\section{OSOBOWY WYMIAR WIARY}

Rozumienie wiary i wnikanie w Mysterium, egzystencjalne dotknięcie natury Boga zbiegają się dla Josepha Ratzingera w osobie Jezusa z Nazaretu. Tajemnica Jezusa z Nazaretu, Boga i człowieka,

${ }^{44}$ „Jest rzeczą normalną, gdy poza nielicznymi wyjątkami, musimy powiedzieć: nie doszedłem do wiary przez prywatne poszukiwania, tylko ją otrzymałem jako dar, który mnie poniekąd wyprzedził” (zob. J. Ratzinger, Wprowadzenie, s. 90-91). Por. J. Ratzinger, Bóg $i$ świat. Z kardynałem Josephem Ratzingerem rozmawia Peter Seewald, Kraków 2001, s. 42 . O możliwości naturalnego poznania Boga odsyłamy do Pisma Świętego i do najbardziej aktualnych dokumentów Kościoła: Mdr 13,1-9; Rz 1,19-20; KO 6; Jan Paweł II, Encyklika Fides e ratio, 19.

45 Por. J. Ratzinger, Bóg $i$ świat, dz. cyt., s. 48.

46 Zob. A. Nichols, The thought..., dz. cyt., s. 108. 
Jego Mysterium, łączy rzeczywistość nadprzyrodzoną z ludzką i ziemską. Bóg wiary chrześcijańskiej jest Bogiem historii, który wszedł w nią w osobie Jezusa z Nazaretu; w Nim jednoczy się darmowość daru i nadprzyrodzone Mysterium, rozumienie i sens, prawda i słowo - Logos. W wierze ma miejsce pierwszeństwo słowa przed myślą, inaczej niż jest to w filozofii, gdzie słowo jest wyprzedzane przez myśl. Wiara pochodzi z zewnątrz, „,ze słyszenia” (Rz 10,17), a nie z rozważania filozoficznego: nie jest czymś wymyślonym: jest następstwem Objawienia i samoobjawienia się Boga, osobowego wypowiedzenia się Boga w Jezusie Chrystusie. Przyjęcie daru łączy się dla człowieka z odpowiedzialnością ciągłego przyswajania go i jest celem kreatywności ludzkiej, pomimo świadomości faktu, że nie można nigdy dogonić tego, co człowieka przerasta, wyprzedza. Zadaniem człowieka jest jednak to, aby sobie coraz bardziej przyswajał otrzymany dar ${ }^{47}$.

Wiara chrześcijańska ma charakter osobowy i jest czymś więcej niż „opowiedzeniem się za duchową podstawą świata”. Jest spotkaniem z człowiekiem Jezusem - powiada Ratzinger - i wyraża się jest słowami „Ja wierzę”, których celem nie jest określenie pewnej abstrakcyjnej idei, lecz osoba. Wiara chrześcijańska nie jest ideą czy abstrakcyjną teorią, jest życiem i to w sensie osobowym. Polega na spotkaniu z Bogiem, który mówi i zaprasza człowieka do miłości ${ }^{48}$. „U początku bycia chrześcijaninem nie ma decyzji etycznej czy jakiejś wielkiej idei, ale jest natomiast spotkanie z wydarzeniem, z Osobą, która nadaje życiu nową perspektywę, a tym samym decydujące ukierunkowanie" ${ }^{\prime 49}$. Personalistyczny charakter wiary u Ratzingera jest tożsamy z jej chrystologicznym ujęciem, ponieważ wyznać „ja wierzę”, to niedokończona formuła, która w pełni brzmiałaby: ,ja wierzę w Ciebie" ${ }^{50}$. Wiara umożliwia spotkanie z osobą Chrystusa,

${ }^{47}$ Por. J. Ratzinger, Wprowadzenie, dz. cyt., s. 90-91.

48 Por. J. Ratzinger, Patrzeć na Chrystusa, dz. cyt., s. 11.

49 Benedykt XVI, Encyklika Deus Caritas est, 1.

50 Zob. J. Ratzinger, Wprowadzenie, dz. cyt., s. 77-79. Zob. też komentarz o tym Stefana von Kempis: „Chrześcijanie wierzą w «ty». Upatrują w Jezusie „przyczyny 
w tym spotkaniu człowiek odnajduje sens świata: „[wiara] jest spotkaniem z człowiekiem Jezusem i w tym spotkaniu doświadcza, że sensem świata jest osoba" ${ }^{51}$. „Człowiek może stać się chrześcijaninem o tyle, o ile wierzy w wydarzenie Jezusa Chrystusa"52. Jeśli bierze się więc pod uwagę chrystologiczne spojrzenie na zagadnienie wiary, to na nowo powraca kwestia naszych rozważań, mianowicie, że wiara należy do płaszczyzny nadprzyrodzonej. Chrystus ,,przez swe życie z Ojca", przez to, że jest w bezpośredniej zażyłości i jedności modlitwy z Nim, nie jest tylko jakimś pośrednikiem czy świadkiem Boga, lecz będąc samym Bogiem, wyraża tajemnicę Swojego Ojca. On jest Mysterium wcielonym w historii: ,jest także obecnością Wiekuistego na tym świecie”. W Nim jest sens, rozumienie, prawda. Logos i Mysterium są tożsame z osobą Jezusa z Nazaretu. „Przez Niego to, co niedotykalne, staje się dotykalne; to, co było dalekie, staje się bliskie"53.

$\mathrm{Z}$ osobowego charakteru wiary, który doprowadził nas do określenia wiary w sensie chrystologicznym, wynikają dwa kolejne Ratzingerowskie podejścia, mianowicie: eklezjologiczne i eschatologiczne. Najbliższe jest spojrzenie eklezjologiczne na wyznanie wiary jako odpowiedź i całej wspólnoty Kościoła - w osobistej odpowiedzi każdego wierzącego - ale również spojrzenie mistyczno-eschatologiczne, wynikające z refleksji nad tajemnicą Paschalną Jezusa Chrystusa, która wyraża sposób życia i bezwzględnego oddania istnienia Syna Bożego ludziom tego świata.

„Ja wierzę” z formuły Credo jest osobistą odpowiedzią człowieka w dialogu chrzcielnym przed przyjęciem Sakramentu Chrztu. Wyznanie wiary nie było nigdy pojmowane w sensie indywidualnym,

wszystkiego" [...]. Wiara jest znalezieniem jakiegoś «Ty». Celem wiary chrześcijańskiej nie jest «sens obiektywny, lecz taki sens, który zna mnie i kocha» i któremu można się powierzyć jak dziecko swojej matce". S. Von Kempis, Benedykt XVI. Podstawy nauczania, Poznań 2006, s. 22.

${ }^{51}$ J. Ratzinger, Wprowadzenie, dz. cyt., s. 77-78.

52 Por. J. Ratzinger, Il sale della terra. Un nuovo rapporto della fede in colloquio con Peter Seewald, Milano 1997, s. 22.

53 Por. J. Ratzinger, Wprowadzenie, dz. cyt., s. 78. 
lecz wspólnotowym. Słowa ,ja wierzę” są wyznaniem wiary całej wspólnoty chrześcijańskiej i życia całego Kościoła. Podmiot wyznający „wierzę" robi to w kontekście wiary, jaką w jedności wyznaje cała wspólnota Kościoła. Na tym tle Ratzinger mówi o eklezjologicznym charakterze odpowiedzi wiary. Przyznaje rację historykom, że Symbol apostolski nie jest jedynym wyznaniem wiary i że z czasem pojawiła się obok liczby pojedynczej ,ja wierzę” również liczba w mnoga, ale należałoby przypomnieć, że ta późniejsza forma była wspólnym oświadczeniem biskupów, pragnących pozostawać w jedności doktrynalnej. Kandydat do chrztu, który przez potrójne wyrzekanie się szatana i służenia mu pragnie nawrócenia swojego „ja” do „Ty” Boga i Jego inności, wyrażając jednocześnie, że prowadzi to do „my” wszystkich, który wierzą w ten sam sposób ${ }^{54}$.

Eschatologiczna perspektywa wiary u Ratzingera przedstawia swoistą interpretację mistyczną tajemnicy paschalnej Jezusa Chrystusa, której istotą jest fakt Jego oddania się ludziom w akcie miłości. Analiza Ratzingera jest bardzo głęboka, ponieważ łączy ujęcie Chrystusa jako uosobienia Mysterium Boga Przedwiecznego z jakością i sposobem Jego egzystowania w świecie, którą objawił najpełniej przez Mysterium męki, śmierci krzyżowej i zmartwychwstania. Jeśli Bóg, który jest Bytem samoistnym w najwyższym tego słowa znaczeniu, czyli jest samą egzystencją i bytowaniem, w Chrystusie staje się obecny w historii i w Jego osobie świat znajduje rację bytu, to wynika $\mathrm{z}$ tego, że sensem świata i człowieka jest również Jego sposób bytowania: Jego bezwzględne oddanie się - miłośćc ${ }^{55}$.

${ }^{54}$ Por. A. Nichols, The thought..., dz. cyt., s. 108-110.

55 Zob. J. Ratzinger, Wprowadzenie, dz, cyt., s. 78. „W Jego życiu, w Jego bezwzględnym oddaniu swego istnienia ludziom mieści się sens świata: On oddaje nam się jako miłość, która także i mnie kocha i przez ten niepojęty dar trwałej miłości, jakiej nie grozi żadna przemijalność, żadne zakłócenie egoizmem, czyni życie wartym życia. Sensem świata jest «Ty», oczywiście tylko to, które samo nie jest czymś problematycznym, lecz jest oparciem dla wszystkiego niewymagającym żadnego innego oparcia". 


\section{MIŁOŚĆ PROPRIUM BYCIA CHRZEŚCIJANINEM}

W tym kluczu Ratzinger rozwija swoje myśli w kierunku aspektu relacyjności wiary, która $\mathrm{w}$ chrześcijaństwie jest podstawą wiary w Trójosobowego Boga; ale z drugiej strony teologia miłości, jako centrum wiary, staje się objawem również jej celowości, ponieważ miłość, którą jest Sam Bóg, jest celem ostatecznym i misją chrześcijaństwa. W tym punkcie chrystologia przechodzi w eschatologię i ukazuje ostateczny kierunek misji całego Kościoła jako ludu wierzących, który jest tak ściśle z Nim złączony, że chrześcijanie podzielą Jego losy. Sekret do zrozumienia wiary chrześcijańskiej polega właśnie na odnalezieniu „Ty” Chrystusa, które jest „oparciem” i które „w całym niespełnieniu i ostatecznej niespełnialności ludzkich spotkań obdarza obietnicą niezniszczalnej miłości, miłości nie tylko pragnącej wieczności, ale ją zapewniającej”56.

Sens istnienia człowieka w ujęciu chrześcijańskim nie jest pojęciem, ale Osobą, która „zna mnie i kocha”, to człowiek może się $\mathrm{Mu}$,powierzyć z gestem dziecka”. W matczynym „Ty” Boga, które objawił Chrystus, znajdują się odpowiedzi na wszystkie pytania człowieka. „Wiara, zaufanie i miłość są ostatecznie jednym i wszelkie treści, wokół których wiara się obraca, są tylko skonkretyzowaniem owego zwrotu obejmującego wszystko, owego «wierzę w Ciebie», owego odkrycia Boga w obliczu człowieka - Jezusa z Nazaretu"57.

$\mathrm{Na}$ końcu, dla posumowania całej teologii wiary Josepha Ratzingera, podajemy jedną z najpiękniejszych, precyzyjnych definicji wiary. Została ona przedstawiona w dziele zawierającym najdojrzalszą myśl teologiczną. Czytamy więc w książce Wprowadzenie w chrześcijaństwo, że „wiara chrześcijańska nie jest ideą, tylko życiem, nie duchem istniejącym dla siebie samego, tylko wcieleniem, duchem w ciele historii i jej «my». Nie jest mistyką, utożsamieniem się ducha z Bogiem, tylko posłuszeństwem i służbą; jest wzniesieniem się ponad siebie, wyzwoleniem $\mathrm{z}$ własnego «ja» przez oddanie

\footnotetext{
${ }^{56}$ Zob. J. Ratzinger, Wprowadzenie, dz, cyt., 78.

57 Tamże, s. 78-79.
} 
się w służbę temu, czego sam nie wykonałem i nie wymyśliłem; uwolniłem się przez podjęcie służby dla całości”58.

\title{
Streszczenie
}

Wiarę należy określić przede wszystkim w kategoriach charytologicznych - jest ona łaską, darmo danym darem. Koncepcja wiary Josepha Ratzingera/Benedykta XVI burzy przekonania tych, którzy za bardzo humanizują wiarę, koncentrując się przesadnie na akcie ludzkim, nadprzyrodzoność wiary pozostawiając na drugim planie. Ratzinger daje pierwszeństwo inicjatywie Boga. Wiara jest przestrzenią nadprzyrodzoną, w której spotykają się mysterium człowieka i Mysterium Boga to, co Boskie w człowieku. Wiara jest tym misterium, które człowieka obejmuje i przenika tak, że Bóg przez łaskę nadprzyrodzoną może się dostać do jego wnętrza. Jest ona tym, co udoskonala człowieka, stanowiącego już dla siebie samego pewnego rodzaju tajemnicy. W doktrynie chrześcijańskiej bowiem przedmiot wiary to nie abstrakcyjna i teoretyczna formuła. Przedmiotem wiary jest osoba - Jezus Chrystus. Wiara dla chrześcijanina jest ostatecznie osobistym spotkaniem z Jezusem z Nazaretu. „U początku bycia chrześcijaninem nie ma decyzji etycznej czy jakiejś wielkiej idei, ale jest natomiast spotkanie z wydarzeniem, z Osobą, która nadaje życiu nową perspektywę, a tym samym decydujące ukierunkowanie" (Deus Caritas est, 1$)$.

Słowa kluczowe: wiara, mysterium, łaska, chrześcijaństwo, teologia, rozumienie, sens, miłość.

Keywords: faith, mysterium, grace, Christianity, theology, understanding, meaning, love.

\begin{abstract}
Faith should be defined first of all in charitological terms - it is a grace, a freely given gift. The conception of faith of Joseph Ratzinger/Benedict XVI destroys the beliefs of those, who humanise faith too much, focusing overly on the human act, putting the supernaturality of faith in the background. Ratzinger gives priority to God's initiative. Faith is a supernatural space, in which the mysterium of man and
\end{abstract}

\footnotetext{
58 Por. tamże, s. 99.
} 
the Mysterium of God - that, which is Divine in man - meet. Faith is that mystery, which encompasses and penetrates man in such a way that God, through a supernatural grace, can enter inside him. Faith is that, which perfects man, who is already for himself some kind of a mystery. In the Christian doctrine, the object of faith is not an abstract and theoretical formula. The object of faith is a person - Jesus

Christ. Faith is eventually a personal encounter with Jesus the Nazarene. "Being Christian is not the result of an ethical choice or a lofty idea, but the encounter with an event, a person" (Deus Caritas est, 1).

\section{Bibliografia}

Blaza M., Kowalczyk D., Traktat o sakramentach, [w]: E. Adamiak , A. Czaja, J. Majewski (red.) Dogmatyka, t. 1, Warszawa 2005.

De Lubac H., Dramat humanizmu ateistycznego, Kraków 2004.

Nicholas A., Myśl Benedykta XVI - Wprowadzenie do myśli teologicznej Josepha Ratzingera, Kraków 2006.

Nicholas A.., The thought of Benedict XVI - An introduction to the Theology of Joseph Ratzinger, New York 2005.

Nichols A., Myśl Benedykta XVI - Wprowadzenie do myśli teologicznej Josepha Ratzingera, Kraków 2006.

Panaro A., Wiara i Mysterium. Prymat Bożego daru w teologii Benedykta XVI, Lublin 2014.

Puyo J., Congar Y., Życie dla prawdy, Jean Puyo rozmawia z ojcem Y. Congarem, Warszawa 1982.

Ratzinger J., Bóg $i$ świat. Z kardynałem Josephem Ratzingerem rozmawia Peter Seewald, Kraków 2001.

Ratzinger J., Fede, ragione, verità e amore. La teologia di Joseph Ratzinger, red. U. Casale, Torino 2009.

Ratzinger J., Il sale della terra. Un nuovo rapporto della fede in colloquio con Peter Seewald, Milano 1997.

Ratzinger J., Moje życie, Częstochowa 2005.

Ratzinger J., O sensie bycia chrześcijaninem, Kraków 2006.

Ratzinger J., Patrzeć na Chrystusa, Kraków 2005.

Ratzinger J., Wprowadzenie w chrześcijaństwo, Kraków 2007.

Sesbüé B., Wierzę, Warszawa 2000.

Von Kempis S., Benedykt XVI, Podstawy nauczania, Poznań 2006.

Antonio Panaro - prezbiter Archidiecezji Warszawskiej, doktor teologii dogmatycznej, wychowawca Archidiecezjalnego Seminarium Misyjnego Redemptoris Mater i wykładowca PWTW w Warszawie 